\title{
Enclosures to Enhance Woody Species Diversity in The Dry Lands of Eastern Tigray, Ethiopia
}

\author{
Emiru Birhane $^{1 *}$, Demel Teketay ${ }^{2}$, Pia Barklund $^{3}$ \\ ${ }^{1}$ Mekelle University, Land Resources Management and Environmental Protection Department, P O Box 231, \\ Mekelle, Ethiopia \\ ${ }^{2}$ Forest Stewardship Council, African Regional Office (FSC Africa), P O Box UP 805, Kumasi, Ghana \\ ${ }^{3}$ Swedish University of Agricultural Sciences, Department of Forest Pathology, P O Box 7060 SE-750 07 Uppsala, \\ Sweden
}

\begin{abstract}
Vegetation and soil seed banks were studied in exclosures and unprotected areas, to investigate the role of exclosures in the rehabilitation of degraded drylands. Woody vegetation was assessed in fifty plots in exclosures and 30 in unprotected areas, each measuring $20 \times 20 \mathrm{~m}^{2}$. Twenty-seven woody species representing eighteen families were observed in exclosures and fourteen woody species representing twelve families were recorded in open area. Higher abundance, density and basal area were found in the exclosure. An expanding population structure in exclosure, and obstructed population structure in open area, showed favorable succession in the set-aside area. In both cases, woody species were absent in the soil seed bank.
\end{abstract}

Keywords: Degradation; Natural Regeneration; Rehabilitation; Soil Seed Bank

\section{Introduction}

Deforestation has been a major problem for quite a long time with serious consequences to Ethiopia. These consequences include decline or loss of biodiversity, degradation of land and water bodies, possible negative effects on the local, regional and global climatic conditions as well as negative impacts on the welfare of human beings. Effects of deforestation have been great and continue unabated. At the close of the twentieth century, the country found itself undergoing rapid and complete deforestation/devegetation in some places. Forest clearances for crop cultivation, unsustainable exploitation of wood for timber, construction and fuel, overgrazing and civil unrest are among the main causes of deforestation in Ethiopia. Thus, at present, small remnant forests, woodlands or shrublands have become restricted to inaccessible areas such as hillsides, mountaintops, and around churches, monasteries, mosques or graveyards, particularly in the northern parts of the country. Larger forest relics are only found in the southern parts of the country.

One of the regions, which has fallen victim to the land degradation problem in the northern parts of the country, is Tigray. In Tigray, the severely degraded lands can be typically characterized by heavily eroded or nutrient deficient soils, hydrological instability, reduced primary productivity and loss of biological diversity. The floral, faunal and microbial diversity of these areas could be reduced, to the extent that they might be changed into wastelands. Past reforestation/afforestation programs in such areas have been unsuccessful due to either total failure or low survival rate of planted species. Several major factors such as unavailability or low availability of propagules, low soil nutrient availability, absence of fungal/bacterial root symbionts or unsuitability of the microhabitats for plant establishment in general and seasonal drought (Verma et al., 1999) may be attributed to such failures.

To circumvent these problems, communities have started to limit interference of people and domestic animals in certain degraded areas (hereafter referred to as exclosures) with the hope of preventing further degradation and promoting their re-vegetation. The main objective of establishing such exclosures is to improve the overall ecological conditions of degraded areas so that they can provide better socio-economic benefits to the local communities. Establishing exclosures is considered advantageous since it is a quick, cheap and a lenient method for the rehabilitation of degraded lands (Bendz, 1986).

It has become a common phenomenon to observe acceleration of plant, but also animal, diversity with time, after the establishment of exclosures. In areas where they have been established, particularly in the northern parts of the country, set-aside areas are among the green spots with considerable woody species diversity (Tefera, 2001). At some places, the local people report that species disappeared in the past have been restored as a result of the exclosures. For instance, in some parts of eastern Tigray, species that had long disappeared from the areas (e.g. Olea europaea subsp. cuspidata and Juniperus procera) re-appeared, densities and diversities of the flora (particularly grasses) and fauna increased, the level of soil erosion decreased, and 
even springs started to flow after exclosures were established (personal observation).

The Bureau of Agriculture and Natural Resources and other development organizations in Tigray have started to avert the land degradation process in the region through massive efforts on soil and water conservation activities, including the establishment of exclosures, with the active involvement of the local communities. Already, some of the degraded areas have become revegetated within just a few years (Medanie, 1997), and it is strongly hoped that the current momentum of restoration of the vegetation would continue leading to rehabilitation of the degraded lands, which would in turn offer the desired socio-economic benefits as well as environmental services.

Despite the fact that exclosures have proved instrumental in the re-vegetation/rehabilitation of degraded lands, knowledge on the diversity, sources of propagules and status of regeneration of the developing flora are lacking. Hence, this study was conducted with the aim of studying the diversity, i.e. species richness and evenness of woody species, investigating the soil seed bank as a possible indicator of the actual or potential source of propagules for the developing flora, and assessing the regeneration status of woody species found in one of the oldest exclosures established in Tigray.

\section{Materials and Methods}

\subsection{Description of the Study Area}

\subsubsection{Geographical Location, Area and Population}

The study was conducted in Aynalem within Wukro district situated $30 \mathrm{~km}$ north of Mekelle, Eastern Zone of Tigray. The site is geographically located at $39^{\circ} 50^{\prime}$ $-39^{\circ} 60^{\prime} \mathrm{E}$ and $13^{\circ} 70^{\prime}-13^{\circ} 81^{\prime} \mathrm{N}$, and covers a total area of 7133 ha. It has five villages and 1800 households, of which 500 inhabit in the actual study area known as Hawza village. The total population in the study area is 3000 . In Hawza village, two sites of similar characteristics were selected for the study at a locality known as Ziban Serawat. One site, covering a total area of $58 \mathrm{ha}$, has been closed for eight years while the other site, covering a total area of 52 ha, has been used for grazing.

\subsubsection{Rainfall, Temperature and Length of Growing Period}

Aynalem Tabia is a dry area with an average annual rainfall ranging from 500 to $600 \mathrm{~mm} \cdot \mathrm{yr}^{-1}$ (NMSA, 2002), although variability of rainfall from year to year is very considerable. The rainy season is mainly between June and September. The average annual temperature at the study site ranges from 15 to $18^{\circ} \mathrm{C}$. It belongs to the Weinadega traditional agroclimatological zone characterised by a hot to warm semi-arid climate. The length of the growing period varies from 75 to 90 days. However, secondary spring rains locally called 'Belg' cause a separate but unreliable growing period, which lasts for 45-65 days.

\subsubsection{Geology and Relief}

The study area is found between the Mekelle and Adigrat plateau. The topography in the study area is mainly mountain plateau with undulating terrain. The Adigrat plateau lies between 2500-2700 $\mathrm{m}$ and is formed on Antalo limestone. The Axum, Mekelle and Sekota plateau lies between 2000 and $2500 \mathrm{~m}$ and is formed on cretaceous shale, limestone and sandstone (TFAP, 1996). The area has an altitude that ranges from 1900 to $2200 \mathrm{~m}$ and a slope that ranges between 5 and $20 \%$.

\subsubsection{Soils}

In the eastern part of the region, where the study area is located, the soils are mostly developed under arid conditions where the weathering process is slow; as a result very shallow lithosols are developed (TFAP, 1996). The locally named soils, such as 'Tsaeda Baehel' and 'Walka', belong to these soil types. Cambisols are also dominant in the arable areas of the study site.

\subsubsection{Land Use and Land Cover}

The intensively cultivated land covers a large portion of the study area. Practically all the land is opened-up for cropping and grazing livestock. Hardly any vegetation cover is seen in the arable lands except in exclosures and some fallow areas of the previous cropping season. Almost about $80 \%$ of the land is under crop cultivation during the cropping season. There are no perennial crops that could cover the major part of the study area. The remaining land is either fallow land used as unimproved pasture or very difficult terrain and not suitable for agriculture. There is high shortage of grazing land, which leads to overstocking during the growing season. After crop harvesting, livestock is allowed into the croplands for grazing. This cycle leaves very extensive areas completely bare by the middle of the dry season, which leads to wind erosion and water erosion during the onset of the next rainy season.

The eastern zone, far worse than other zones, is the most degraded part of the region and almost devoid of vegetation (Tesfaye, 1996). As community forestry practices there are different area exclosures established since 1993, and community tree nurseries managed by the communities. Dispersed trees on croplands, trees and shrubs in home gardens, improved fallow, trees and shrubs on terraces, protection of waterways and gullies, living fences as well as trees and shrubs on pastures are the major agroforestry practices. Some of the woody species found in these practices are Faidherbia albida, Acacia etbaica, Eucalyptus spp., Cordia africana, Schinus molle, Euphorbia spp., Optuntia ficus-indica, Agave sisalana, etc. In this study, plant nomenclature follows Friiss (1992) and the Flora of Ethiopia (Edwards et al., 1995; Hedberg et al., 1995). 

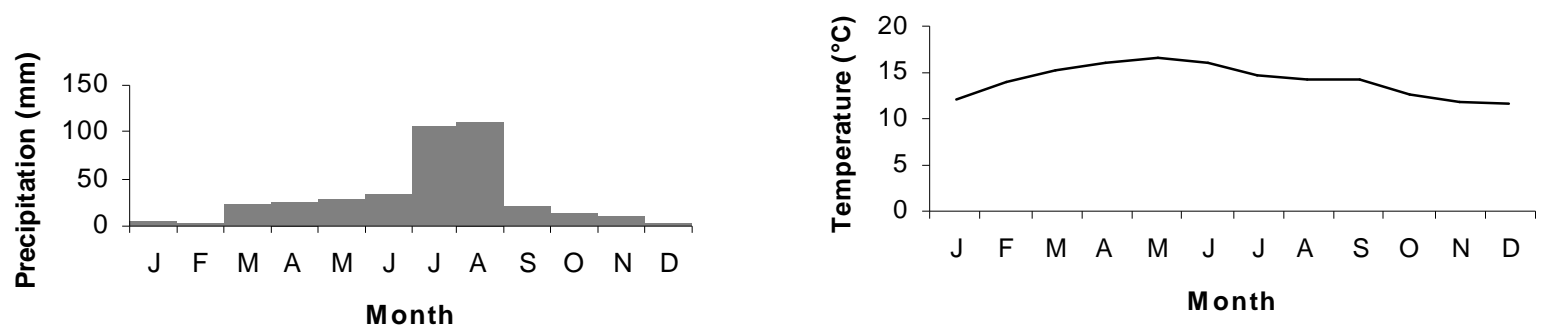

Figure 1. Mean monthly precipitation and temperature for Mekelle town (1991- 2001)

\section{Methods}

\subsection{Species Abundance, Density and Diversity}

To determine the species composition, abundance, density and diversity of woody plants, line transects were laid out parallel to each other and with a north to south orientation in the exclosure and open grazing land. The distance between two consecutive parallel transect lines was $200 \mathrm{~m}$. Along the transect lines, sample quadrats measuring $20 \mathrm{~m} \times 20 \mathrm{~m}\left(400 \mathrm{~m}^{2}\right)$ were laid down at $50 \mathrm{~m}$ intervals from each other. The quadrats were marked using plastic ribbon and four wooden pegs. A total of 50 and 30 quadrats were established in the exclosure and open grazing land, respectively. More quadrats were sampled in the exclosure since the variability was much higher than in the grazing land. In each quadrat the following measurements were made: (I) the identity of all woody plants was determined and the total number as well as height of individuals (using a graduated stick) of each species were recorded; (II) the diameters of saplings and trees were measured just above the ground (basal diameter) and at $0.5 \mathrm{~m}$ height, respectively using a calliper and diameter tape. For regenerated seedlings (height $<0.5 \mathrm{~m}$ ), only their number was recorded. Individual woody categorization was made as height < $0.5 \mathrm{~m}$ and $\mathrm{dbh}<2.5 \mathrm{~cm}$ for seedlings, $\mathrm{h}>0.5 \mathrm{~m}$ and $\mathrm{dbh}<5 \mathrm{~cm}$ for saplings and $\mathrm{h}>0.5 \mathrm{~m}$ and $\mathrm{dbh}>5 \mathrm{~cm}$ for trees. For species that were difficult to identify in the field, herbarium specimens were collected, pressed, dried and transported to the National Herbarium in the Department of Biology, Addis Ababa University, for proper identification.

\subsection{Ground Cover of Herbs}

To estimate the abundance of herbaceous species in the exclosure and open grazing land, a small plot measuring $4 \mathrm{~m} \times 4 \mathrm{~m}\left(16 \mathrm{~m}^{2}\right)$ was placed in the middle of each of the quadrats described above. In this plot, the proportion of cover by each herbaceous species was estimated visually (Sutherland, 2000).

\subsection{Regeneration Status}

Examination of the population structure of plants, employing either height or diameter classes, has been used to provide a rough idea about the status of regeneration of woody plants (Tamrat, 1994; Peter, 1996; Demel, 1998; Getachew, 1999; Mekuria et al.,
1999; Tadesse et al., 2000; Tefera, 2001; Alemnew, 2001; Feyera et al., 2002). To assess the regeneration status of woody plants, through examination of their population structures, all individuals encountered in the quadrats were grouped arbitrarily into: (i) height classes: < $0.5 \mathrm{~m}$ (seedlings), 0.5 - $3 \mathrm{~m}$ (saplings) and > $3 \mathrm{~m}$ (trees); and (ii) diameter classes: $<2.5 \mathrm{~cm}, 2.5-5$ $\mathrm{cm}$ and $>5 \mathrm{~cm}$. The categorization considers the life form and taxonomic structure. Then, histograms were drawn to see the population structure of a few of the woody plants.

\subsection{Soil Seed Banks}

The assessment of soil seed banks from both sites was carried out mid-December. Considering the size of the study area samples were taken to represent the main floristic vegetation types. The quadrats used to record composition, height and diameter of woody plants along the line transects were used to collect soil samples for seed bank analyses (Mekuria et al., 1999; Lyarru, 1999; Tefera, 2001). In each of the quadrats, five plots measuring $15 \mathrm{~cm} \times 15 \mathrm{~cm}$ were laid out, one at the center and the other four at the four corners. From each plot, three soil layers of three $\mathrm{cm}$ thickness each, i.e. a total depth of nine centimetres, were collected using a knife and spoon. Then, similar layers from these five plots within a quadrat were mixed to form a composite sample in order to reduce variability within the quadrats. The composite sample for each soil layer was again divided into five equal parts among which one was selected randomly as a working soil sample (Tefera , 2001). A total of 240 soil samples, i.e. 150 from the exclosure and 90 from the open grazing land, were collected. The soil samples were transported daily from the sites to a safe storing place in Wukro town. Then, the soil samples were transported to the Forestry Research Center (FRC) where they were sieved to recover seeds of woody plants. Four sieve sizes, i.e. 1 $\mathrm{mm}, 1.6 \mathrm{~mm}, 2 \mathrm{~mm}$ and $3.15 \mathrm{~mm}$, were selected assuming the seed sizes of the different species are within these ranges. Viability of seeds recovered by sieving was determined by cutting tests (Demel and Granstrom, 1995) after which they were identified. The sieved soils were then transported to the Ethiopian Agricultural Research Organisation (EARO) headquarters where they were incubated in a glasshouse to stimulate germination of seeds. In the glasshouse, the soil samples were spread as thinly as possible on plastic 
trays and watered every day. Seedlings started germinating from the soil samples within a week. The seedlings were identified, counted and removed. Those that were difficult to identify were transplanted into polythene bags filled with a soil medium and left to grow until they let themselves for identification. Those difficult to identify were categorized as unidentified species. Thus, soil sieving together with seedling emergence method was used to assess the status of the soil seed banks.

\subsection{Data Analysis}

The sum of all species encountered in the quadrats of both the exclosure and open area was used to determine the species richness in the study site. Similarly, the abundance, basal area, Important Value Index (IVI) of each woody species, and the diversity values of woody plants in the exclosure and open area were calculated using diversity indices, species richness, evenness and heterogeneity (Krebs, 1999; Magurran, 1996). In addition to the different indices used a one-way ANOVA test was employed to test the significance of differences.

To assess the ground cover of herbaceous species in the exclosure and open area, the proportions of cover of all herbs in each plot were categorized into ground cover classes (Heinz, 1972). To understand the regeneration status of woody plants and some important tree species a histogram was constructed using frequency distribution of diameter and height classes of different arbitrary classes. The seed bank was analyzed by studying the woody species composition, density of seeds in the soil and horizontal and vertical distribution of seeds (Demel and Granström, 1995).

\section{Results and Discussion}

\subsection{Composition of Woody Species}

The total number of woody plant species recorded in the study area, in both the exclosure and open grazing area, was 39, among which 31 were naturally growing species and eight were planted. In the exclosure 27 plant species representing 18 families were recorded. Out of the total woody species encountered in the study quadrats, $37 \%$ were trees, $52 \%$ shrubs and the rest were woody herbs. In the open grazing area, 14 species were recorded representing 12 families. Here, trees constituted $50 \%$ of the total woody species and shrubs $50 \%$. About 14 species were recorded both in the exclosure and open area while 13 species were found only in the exclosure area.

The three most abundant species in the exclosure were Acacia etbaica, Leucas oligocephala, and Oncoba spinosa (Table 1). Of all the species A. etbaica represented about $64 \%$ of the total abundance. Similarly, A. etbaica, Euclea racemosa subsp. schimperi and Leucas oligocephala, were the abundant species in the open area (Table 2). A. etbaica was the most dominant species $(60 \%)$.

The composition of the woody vegetation in exclosures of degraded land depends largely on the time since closure, the original vegetation and past disturbance history. The climatic and edaphic conditions could also have a significant effect on the type of species appearing. More time for the exclosure to establish leads to a greater richness in plant communities (Pielou, 1975). Woody species appearance in exclosures indicates a long period of protection, allowing regeneration of shrubs and trees, exemplified in Ethiopia (Kebrom, 2001; Tefera, 2001) and in Eritrea (Medaine, 1997).

The vegetation composed by the woody species and the ground cover of herbaceous species was denser in the exclosure than in the open area. The difference in density was significantly greater for the herbaceous than for the woody species $(\mathrm{p}=0.01)$. This indicates that the disturbance in the open area was mainly due to the high grazing intensity throughout the year.

Acacia etbaica was the most dominant species in both the exclosure and open area. The same result was also found in Sekota by Tefera (2001). The importance value index is higher in the open area than in the exclosure, while basal area and density is higher for this species in the exclosure $(\mathrm{P}=0.01)$. Hence the species occupies more space in relation to other species in the open area than the exclosure. The dominance of $A$. etbaica could be because the site was originally dominated by this species (history of the site and reports office of agriculture of the site). Even though the area was changed into agricultural land, farmers left important woody species while clearing for shade, fuelwood and to put crop residues, especially trees with an umbrella crown and shorter in height. Acacia etbaica is also a pioneer species; such species are more dominant in disturbed sites (Denslow, 1987), taking advantage of primary succession.

The Importance Value Index (IVI) gives a realistic value of dominance. According to the IVI Acacia etbaica, Aloe berhana, Euclea racemosa subsp. schimperi, Leucas oligocephala and Carissa edulis are the most dominant species in the exclosure. On the other hand, Acacia etbaica, Euclea racemosa subsp. schimperi, Leucas oligocephala, and Echinopis hispidus are the most dominant species in the open area. The higher IVI value of these species is related to the higher basal area, abundance, density and frequency distribution they have. Abundance of woody species indicates the future recovery of the open area would be successful if it became closed. 
Table 1. Abundance (AB), density (DE), frequency (FR), basal area (BA) and Importance Value Index (IVI) of woody plants sampled in an exclosure in northeast Ethiopia

\begin{tabular}{|c|c|c|c|c|c|c|c|c|}
\hline No. & Species & Family & Life Form & $\mathrm{AB}$ & $\mathrm{DE}$ & FR & BA & IVI \\
\hline 1 & Acacia etbaica Schweinf. & Fabaceae & Tree & 1724 & 862 & 100 & 20,46 & 59,34 \\
\hline 2 & Leucas oligocephala (Vahl)Smith & Lamiaceae & Shrub & 327 & 163,5 & 6 & 0,01 & 4,51 \\
\hline 3 & Oncoba spinosa Forrsk. & Flacourtiaceae & Shrub & 104 & 52 & 26 & 0,19 & 3,32 \\
\hline 4 & Taverniera abyssinica A. Rich. & Fabaceae & Shrub & 81 & 40,5 & 12 & 0,13 & 2,01 \\
\hline 5 & Echinopis hispidus O.hoffm. & Asteraceae & Woody herb & 68 & 34 & 20 & 0,20 & 2,48 \\
\hline 6 & Rhus vulgaris Meikle. & Anacardiaceae & Tree & 56 & 28 & 2 & 0,00 & 0,84 \\
\hline 7 & Carissa edulis Vahl. & Apocynaceae & Tree & 52 & 26 & 38 & 0,14 & 3,40 \\
\hline 8 & Euclea racemosa subsp. schimperi (A.DC.) Dandy. & Ebenaceae & Shrub & 47 & 23,5 & 74 & 0,07 & 5,64 \\
\hline 9 & Senna singueana (Del.) Lack. & Caesalpiniaceae & Shrub & 46 & 23 & 28 & 0,13 & 2,64 \\
\hline 10 & Maytenus senegalensis (Lam.) Exell & Celastraceae & Shrub or tree & 27 & 13,5 & 24 & 0,17 & 2,19 \\
\hline 11 & Aloe berhana Tad. & Aloaceae & Woody herb & 24 & 12 & 70 & 0,33 & 5,47 \\
\hline 12 & Jasminum abysinicum $\mathrm{Pax}$ & Oleaceae & Shrub & 22 & 11 & 2 & 0,00 & 0,41 \\
\hline 13 & Tsamo ( Vernacular name) & Unidentified & Shrub & 20 & 10 & 14 & 0,01 & 1,20 \\
\hline 14 & Opuntia ficus-indica (L.) Mill & Cactaceae & Bush & 13 & 6,5 & 8 & 0,00 & 0,70 \\
\hline 15 & Meriandra bengalensis (Konig ex Roxb.) Benth & Lamiaceae & Shrub & 13 & 6,5 & 2 & 0,00 & 0,30 \\
\hline 16 & Rhus glutinosa A.Rich. & Anacardiaceae & Shrub or tree & 11 & 5,5 & 32 & 0,04 & 2,33 \\
\hline 17 & Showha (Vernacular name) & Unidentified & Shrub & 5 & 2,5 & 2 & 0,00 & 0,20 \\
\hline 18 & Maytenus arbutifolia (A. Rich.) Wilczek. & Celastraceae & Shrub & 3 & 1,5 & 4 & 0,00 & 0,31 \\
\hline 19 & Asparagus africanus Lam. & Asparagaceae & Shrub & 3 & 1,5 & 2 & 0,01 & 0,18 \\
\hline 20 & Agave sisalana Perr. & Agavaceae & Woody herb & 3 & 1,5 & 2 & 0,00 & 0,18 \\
\hline 21 & Ehretia cymosa Thonn. & Boraginaceae & Shrub or tree & 2 & 1 & 6 & 0,00 & 0,43 \\
\hline 22 & Grewia ferruginea A.Rich & Tiliaceae & Shrub or tree & 2 & 1 & 2 & 0,00 & 0,16 \\
\hline 23 & Osyris quadripartita Decn. & Santalaceae & Tree & 2 & 1 & 4 & 0,00 & 0,29 \\
\hline 24 & Commiphora africana (A.Rich.) Engl. & Burseraceae & Tree & 1 & 0,5 & 6 & 0,03 & 0,45 \\
\hline 25 & Withania somnifera (L.) Dunal & Solanaceae & Shrub & 1 & 0,5 & 8 & 0,01 & 0,56 \\
\hline 26 & Indigofera arrecta Hochst.ex A.Rich. & Fabaceae & Shrub & 1 & 0,5 & 2 & 0,02 & 0,18 \\
\hline \multirow[t]{2}{*}{27} & Ziziphus spina-christi (L.) Desf. & Rhamnaceae & Tree & 1 & 0,5 & 4 & 0,01 & 0,29 \\
\hline & Total & & & 2659 & 1329,5 & 500 & 21,96 & 99,99 \\
\hline
\end{tabular}

The greater variability of abundance of species distribution in the exclosure could be because of the special niche requirement (Pielou, 1975), the time of immigration of the species may be recent and the need for special micro-site requirements for regeneration. The difference in species abundance distribution in non-exclosure areas could be attributed to the excessive disturbance, overgrazing and special palatable characteristic of the species.

The basal area distribution for the exclosure indicates the contribution of each diameter class to the total basal area is considerable and smaller diameter class individuals have a higher contribution to the total basal area indicating early succession. Whereas, in the open area, the higher basal area is contributed through big individual classes indicating the open area is in its oldest stage or in poor reproduction condition (Figure 2 ). The greater difference in basal area between the exclosure and open area could be due to the high number of multi-stemmed trees in the exclosures, leading to bigger diameters. The heights of the majority of trees in both sites are almost the same, indicating that both sites probably have equal site quality (Figure 3 ).

\subsection{Diversity}

Exclosures show a positive impact on density but they didn't show a positive impact on diversity (Table 3 ).

Results from the calculation of diversity indices reveal that there is higher diversity of woody species in the open area than the exclosure $(\mathrm{P}=0.05)$. 
Table 2. Abundance (AB), density (DE), frequency (FR), basal area (BA) and Importance Value Index (IVI) of woody plants sampled in unprotected grazing land in northeast Ethiopia

\begin{tabular}{|c|c|c|c|c|c|c|c|c|}
\hline No. & Species & Family & Life form & $\mathrm{AB}$ & $\mathrm{DE}$ & FR & $\mathrm{BA}$ & IVI \\
\hline 1 & Acacia etbaica Schweinf. & Mimosaceae & Tree & 455 & 379,2 & 100 & 9,35 & 85,1 \\
\hline 2 & Euclea racemosa subsp. schimperi (A.DC.) Dandy & Ebenaceae & Shrub & 72 & 60,0 & 8 & 0,00 & 3,2 \\
\hline 3 & Leucas oligocephala (Vahl) Smith & Lamiaceae & Shrub & 47 & 39,2 & 20 & 0,04 & 2,4 \\
\hline 4 & Echinopis hispidus O.Hoffm. & Asteraceae & Woody herb & 42 & 35,0 & 14 & 0,00 & 1,9 \\
\hline 5 & Aloe berhana Tad. & Aloaceae & Woody herb & 35 & 29,2 & 24 & 0,01 & 1,6 \\
\hline 6 & Maytenus senegalensis (Lam.) Exell. & Celastraceae & Shrub or tree & 24 & 20,0 & 14 & 0,00 & 1,1 \\
\hline 7 & Oncoba spinosa Forrsk. & Flacourtiaceae & Shrub & 17 & 14,2 & 10 & 0,00 & 0,8 \\
\hline 8 & Carissa edulis Vahl. & Apocynaceae & Tree & 16 & 13,3 & 26 & 0,00 & 0,7 \\
\hline 9 & Rhus glutinosa A.Rich. & Anacardiaceae & Shrub or tree & 15 & 12,5 & 6 & 0,00 & 0,7 \\
\hline 10 & Rhus vulgaris Meikle. & Anacardiaceae & Tree & 10 & 8,3 & 32 & 0,04 & 0,7 \\
\hline 11 & Senna singueana (Del.) Lack & Caesalpiniaceae & Shrub & 5 & 4,2 & 10 & 0,11 & 1,0 \\
\hline 12 & Jasminum abyssinicum Pax. & Oleaceae & \multirow{2}{*}{$\begin{array}{l}\text { Shrub } \\
\text { Shrub or tree }\end{array}$} & 5 & 4,2 & 30 & 0,06 & 0,6 \\
\hline 13 & Ehretia cymosa Thonn & Boraginaceae & & 2 & 1,7 & 2 & 0,00 & 0,1 \\
\hline \multirow[t]{2}{*}{14} & Osyris quadripartita Decn. & Santalaceae & Tree & 1 & 0,8 & 2 & 0,00 & 0,0 \\
\hline & Total & & & 746 & 621,7 & 298 & 9,62 & 100,0 \\
\hline
\end{tabular}

Enclosure

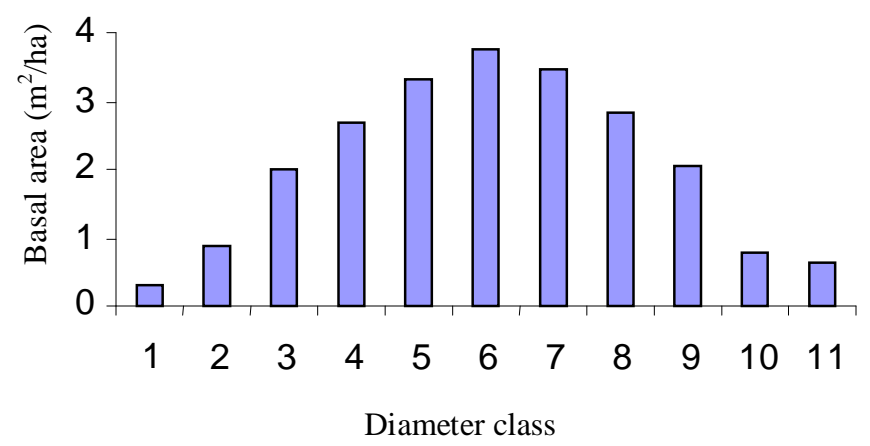

Non enclosure

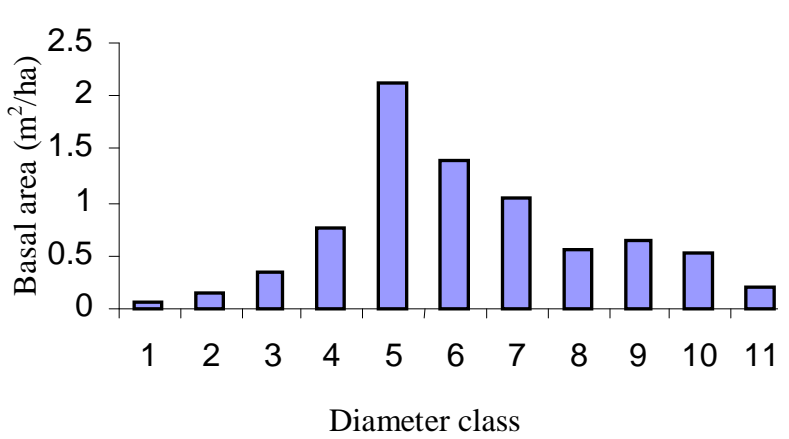

Figure 2. Basal area $\left(\mathrm{m}^{2} / \mathrm{ha}\right)$ distribution of all woody species: Diameter class $(\mathrm{cm}): 1<5 \mathrm{~cm}, 2=5-10,3=10-15,4=$ $15-20,5=20-25,6=25-30,7=30-35,8=35-40,9=40-45,10=45-50,11=>50 \mathrm{~cm}$ 
All woody species
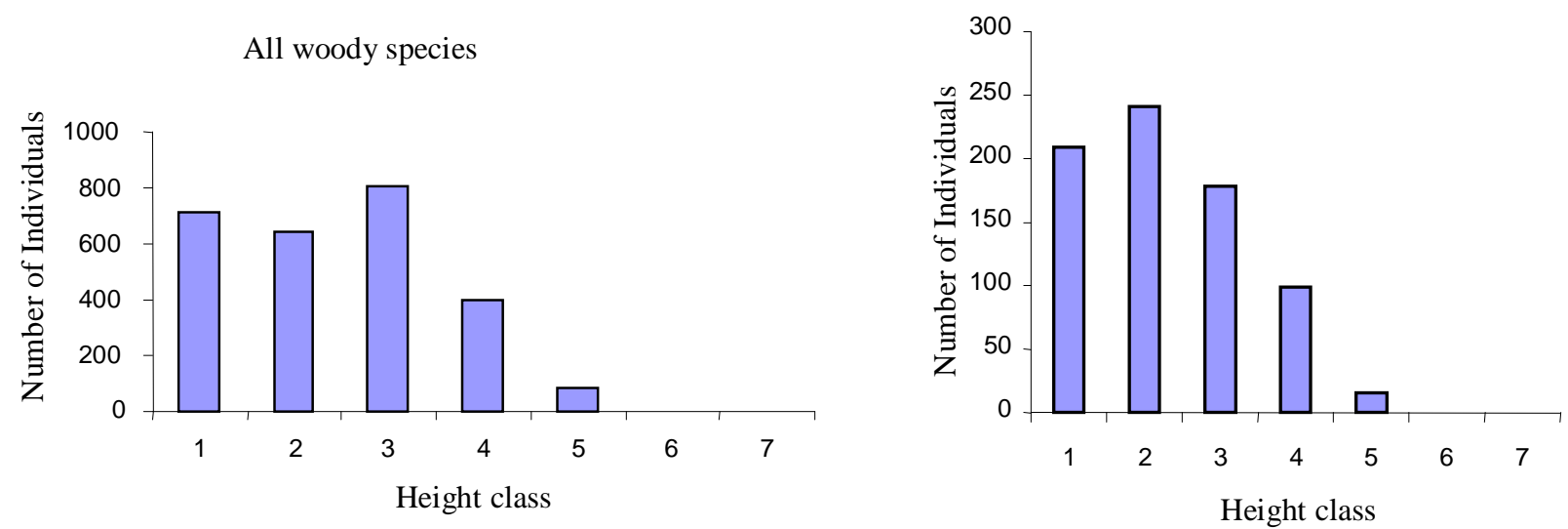

Figure 3. Frequency distribution of height classes $(\mathrm{m})$ for all woody species of exclosures and non-exclosures: Height class $1=<0.5 \mathrm{~m}, 2=0.5-1,3=1-1.5,4=1.5-2,5=2-2.5,6=2.5-3,7=>3 \mathrm{~m}$.

This is because the Shannon diversity index is highly influenced by the number of dominant and rare species present. The dominance for A. etbaica is $64 \%$ for the exclosure while $60 \%$ in the open area. The species diversity of the open areas was found to be higher than the closed areas in Eritrea by Medanie (1997) and in Tanzania by Mwalayosi (2000). The Simpson measure of evenness also shows a higher value for the open area. This is because of the relative abundance of each species. The more the relative abundance of species differs, the lower the evenness is (Avena, 2000). On the other hand, the species richness in the exclosure is higher than in the open area. The average number of species per plot is also higher in the closed area than in the open areas, indicating more diversity in the exclosure. The two measures of richness (Margalefs and Menhicks index) are higher for the exclosure. The two diversity indices used to estimate the total number of species did not estimate precisely. This is because the number of species represented by 1 and 2 individuals affects the indices.

\subsection{Ground Cover of Herbs}

The ground cover is much better in the exclosure than in the open area, thus supporting further regeneration because of better soil conditions and microclimate (Table 4).

\subsection{Regeneration Status}

In the exclosure the diameter distribution of the community of all woody species shows an inverted $\mathbf{J}$ shape (Figure 4), with more abundant individuals in the lower diameter classes. It indicates active and uniform regeneration. $45 \%$ of the individuals had a diameter distribution of less than $5 \mathrm{~cm}$. The most abundant species (Acacia etbaica) also has an inverted J-distribution. About $50 \%$ of its population has a diameter less than $5 \mathrm{~cm}$. Others like Leucas oligocephala, Euclea racemosa subsp. schimperi and Maytenus senegalensis also have an expanding type of population structure. Rhus vulgaris shows an obstructed type of population structure and has low numbers of individuals in the lower diameter classes. The percent of seedling, sapling and trees for the exclosure was $60 \%, 20 \%$ and $19 \%$ respectively.

The diameter distribution for the non-exclosure also shows an inverted $\mathrm{J}$ shape (Figure 5). The percent of seedlings, saplings and trees was $27 \%, 58 \%$ and $15 \%$ respectively. Acacia etbaica, the most abundant species in the non-exclosure shows more individuals in the middle, and less in the lower diameter classes indicating the inability to reach higher diameter classes.

There is no problem of regeneration but the regenerated seedlings have been trampled by the free grazing animals. Species like Maytenus senegalensis and Euclea racemosa subsp. schimperi had more gaps in the distribution. Mature trees and seedlings are limited. It shows a more disturbed regeneration pattern. There was very low abundance of tree seedling individuals in the lower diameter classes of the non-exclosure and much dominated with shrubs of middle diameter class.

The population structure helps to study the regeneration pattern of a species (Swamy et al. 2000). The major species in the exclosure such as Acacia etbaica and Leucas oligocephala are represented by high seedling proportion. These species could have seeds that are easily germinating and match their seed dispersal to the rainy season (Demel , 1996). The high proportion of seedlings in the exclosure showed the potential for the restoration of a woody community. A lower proportion of seedlings of the same species in the open area were less promising. 

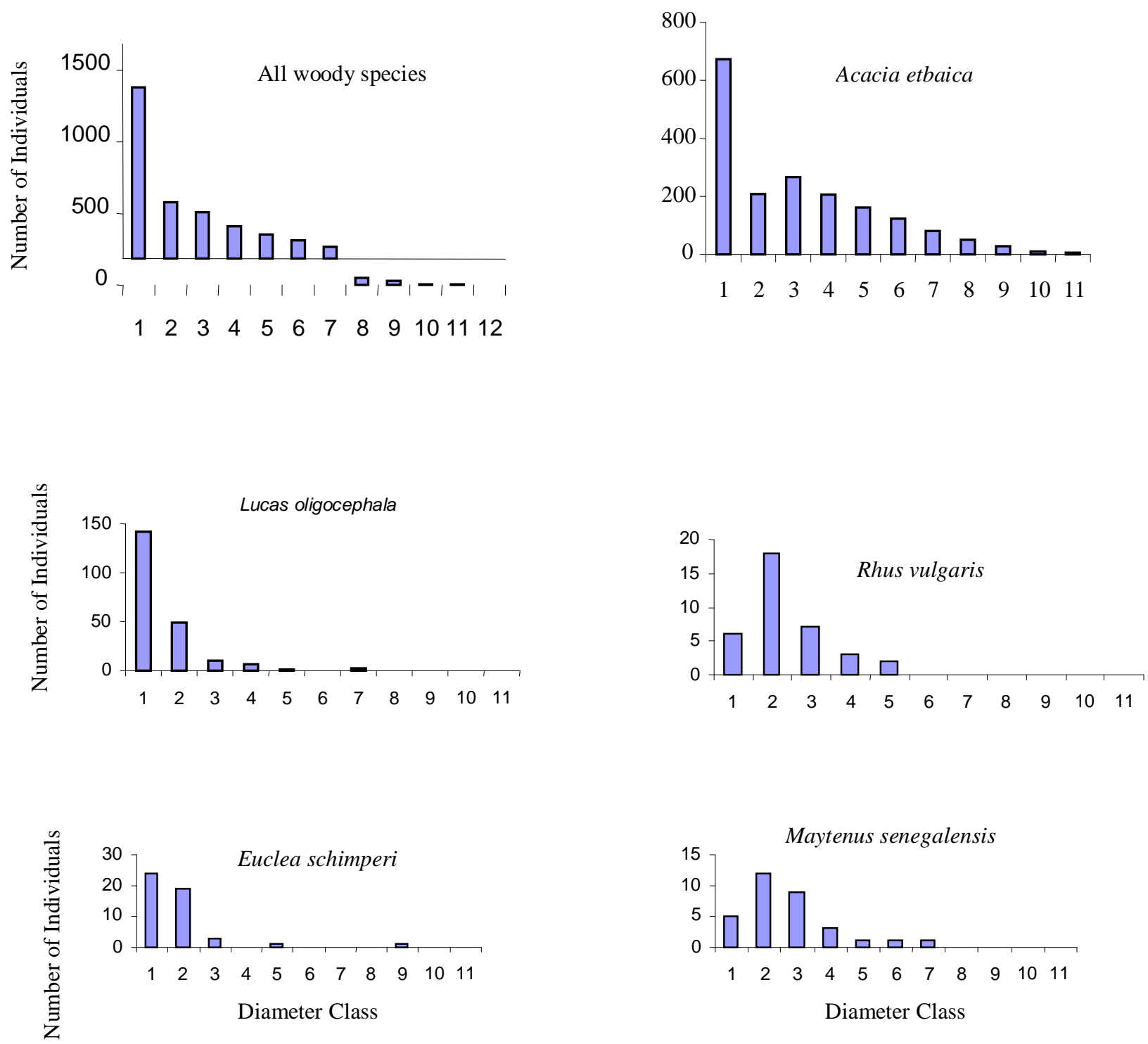

Figure 4. Diameter class $(\mathrm{cm})$ distribution of all woody plants encountered in all plots of the exclosure and some major woody plants. Diameter class: $1<5 \mathrm{~cm}, 2=5-10,3=10-15,4=15-20,5=20-25,6=25-30,7=30-35,8=35$ $40,9=40-45,10=45-50,11=>50 \mathrm{~cm}$ 

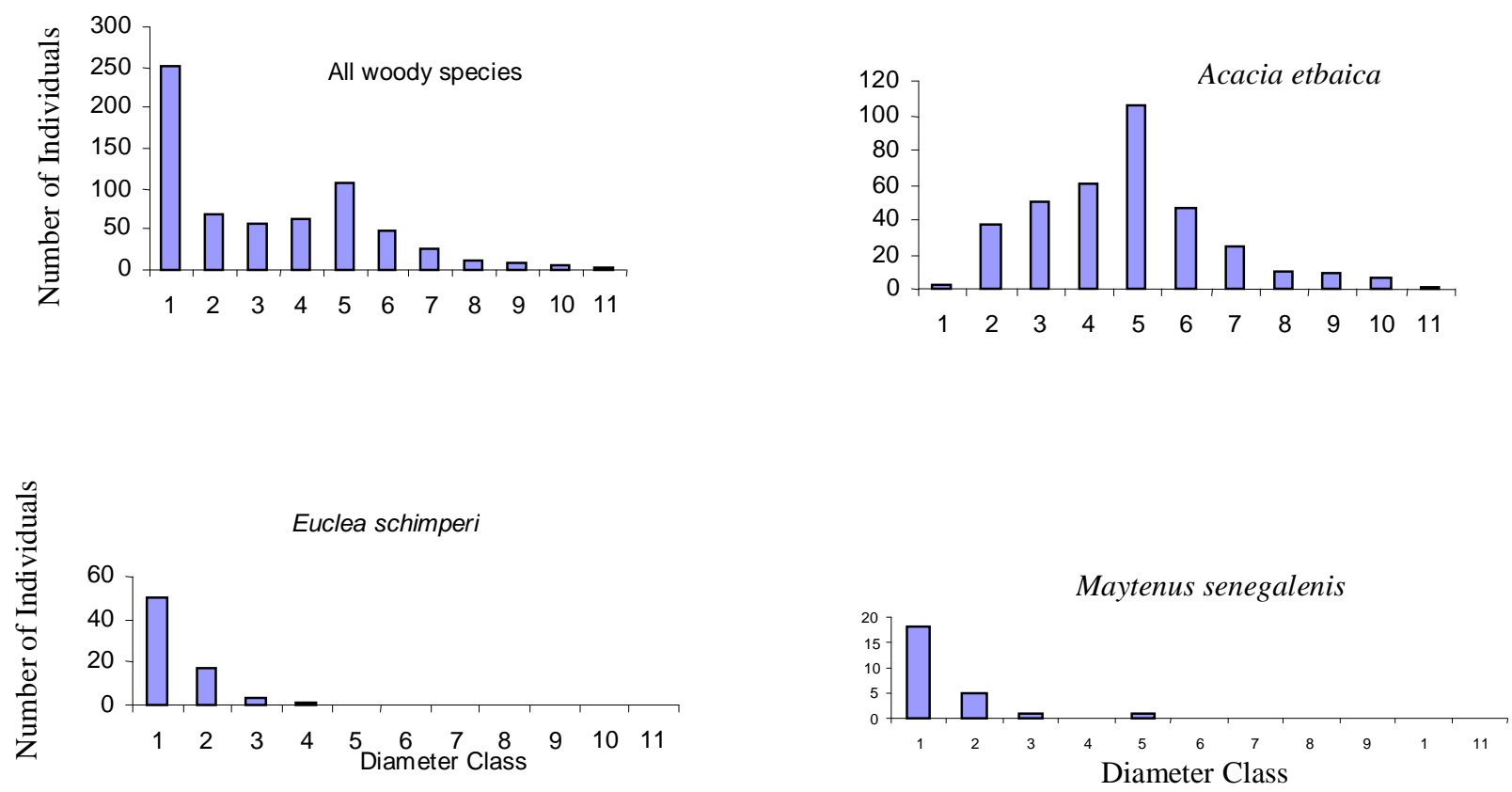

Figure 5. Diameter class $(\mathrm{cm})$ distribution of all woody plants encountered in all plots of non-exclosures and some of the major woody plants. Diameter classes: $1<5 \mathrm{~cm}, 2=5-10,3=10-15,4=15-20,5=20-25,6=25-30,7=30$ $35,8=35-40,9=40-45,10=45-50,11=>50 \mathrm{~cm}$

Table 3. A summary of diversity indices of woody species for exclosures and non-exclosures

\begin{tabular}{lcc}
\hline Diversity index & Value for exclosure & Value for non-exclosure \\
\hline Number of individuals (N) & 2659 & 746 \\
Species Richness & & 14 \\
Observed number of species (S) & 27 & 14 \\
Chaos index (C) & 29 & 15 \\
Jack knife index (J) & 32 & 1.96 \\
Margalefs index (Dmg) & 3.29 & 0.512 \\
Menhicks index & 0.524 & \\
Species Evenness & & 0.573 \\
Shannon evenness (E) & 0.455 & 1.640 \\
Berger Parker diversity (1/d) & 1.562 & \\
Species Heterogeneity & & 1.514 \\
Shannon (H') & 1.468 & 2.548 \\
Simpson (1/D) & 2.272 & \\
\hline
\end{tabular}

Table 4. Ground Cover Class: $1=1-25 \%$ (poor cover), $2=26-50 \%$ (thin cover), $3=51-75 \%$ (intermediate), $3=76-$ $100 \%$ (good covers)

\begin{tabular}{lllll}
\hline Site & \multicolumn{2}{l}{ Ground Cover Classes } & & \\
& 1 & 2 & 3 & 4 \\
\hline Exclosure & 0 & $1(2 \%)$ & $3(6 \%)$ & $46(92 \%)$ \\
Open Area & $5(16.7 \%)$ & $17(56.6 \%)$ & $5(16.7 \%)$ & $3(10 \%)$ \\
\hline
\end{tabular}


Since the exclosure is protected from interference, there is a high probability of growing to the next diameter class, which gives a sound population structure. The most dominant Acacia etbaica also shows an inverted $\mathrm{J}$ - shape distribution. The high proportion of seedlings shows a self-maintaining population structure implying the probability of being the main species in the recovery of the woody community.

In the open area A. etbaica, the dominant species, contributes much to the community structure, but has a discontinuous type of population distribution with a higher frequency of middle class diameters. The low proportion of seedlings is probably because of grazing or trampling and shows that the open area has a lower potential for rehabilitation than the exclosure. Cutting for fuelwood may decrease the probability to recruitment to higher diameter classes.

The less common species Euclea racemosa subsp. schimperi and Leucas oligocephala in the exclosure occur mostly as bushes with a high number of individuals at the lower classes, even more so for Euclea racemosa subsp. schimperi than in the open area. Trees in higher diameter classes occur irregularly or are missing. This pattern indicates a good reproduction but a bad recruitment to bigger trees in both the exclosure and the open area. Bigger trees of Euclea racemosa subsp. schimperi may be cut, since the species is important for ceremonies. Species like Maytenus senegalensis, and Rhus vulgaris shows a discontinuous or periodic recruitment. The distribution indicates that the number of seedlings may be sufficient to maintain the population. Bigger trees of these less common species might be remnants from the previous vegetation.

The exclosure has a sound type of regeneration, represented both by the community structure and individual species population structure. The unprotected area shows a more obstructed type of structure, mainly indicated by the dominant species. These revealed that the high level of protection in the exclosure helps the regeneration of woody species.

\subsection{Composition and Density of Soil Seed Banks}

A total of 29 herbaceous species (data from germination and sieving combined) was obtained from the top $9 \mathrm{~cm}$ in the soil seed banks of both land uses. 29 herbaceous species belong to the exclosure and 23 species were found in the open area. There were no woody species obtained from the soil seed bank, all seeds found were herbaceous. There is also a very low number of woody species in studies made in the northern part of Ethiopia by Tefera (2001), Kebrom and Tesfaye (2000) and Kebrom (2001) as compared to other areas studied in afromontane and rift valley biotopes by Demel (1997), Feyera (1998) and Mekuria (1999). The lack of woody seeds could be related to the high level of degradation and erosion in the northernmost part of the country, as the seed bank density is negatively affected by erosion (Bergston, 1993; Granström, 1986). Woody plants generally have low seed numbers (Demel and Granstrom, 1995) and are short lived in the soil (Demel , 1997). Instead most woody seeds germinate soon after rain indicating that they rely on a seedling bank. This is a common regeneration strategy probably appropriate for tropical woody species as seed losses can be expected for many reasons (Jerry, 1992). Acacia etbaica sets its seeds in line with the rainy season and seems to have a strategy of a seedling bank rather than a seed bank. The reason why no seeds were found in the soil seed bank either for the dominant species Acacia etbaica or the other woody species in the exclosure could be that the soil seed bank was collected at the end of the dry season, when all seeds had germinated. For the open area a lack of seedlings is probably not due to a lack of seeds, it is more likely that they disappear after germination through grazing and trampling. There are probably also other reasons why seeds can be missing like predation. Loss of acacia seeds through predation was reported by (Leck et al.,1994). High seed number of herbaceous and grass species both in the exclosure and the unprotected area may link to a prolonged dry season, which helps with the accumulation of dormant seeds.

The total number of seeds recovered was 1663 for the exclosure (sample area $=11250 \mathrm{~cm}^{2}$ ) and 924 for the open area (sample area $=6750 \mathrm{~cm}^{2}$ ) up to a depth of $9 \mathrm{~cm}$. Many of the seeds in both the exclosure and open area were recovered from sieving. Only $6 \%$ are obtained from incubation. The total number of viable seeds obtained both from sieving and incubation shows a seed bank density of about $1479 / \mathrm{m}^{2}$ for the exclosure and $1369 / \mathrm{m}^{2}$ for the unprotected area to a depth of $9 \mathrm{~cm}$. That is comparable with investigations in dry tropical ecosystems that have revealed 48-1890 seeds $/ \mathrm{m}^{2}$ (Garwood, 1989) and 8-67 species. The lower densities are found in drier areas.

The density of species decreased with depth in both land uses. High seed density in the upper portion of the soil seed bank indicates that the contribution of the standing vegetation is recent, since seeds in the superficial layer can be assumed to form part of that seasons seed input (Lyarru, 1996). It is interesting and cannot be easily explained why the soil seed bank in the two land-uses were almost the same and at the same time the ground cover of herbs differed substantially between the two land-uses.

The diversity of the seeds in the exclosure is higher (Shannon's H' = 2.1) than the open area (Shannon's $H^{\prime}=2.0$ ). The diversity decreases with depth in both land uses. Sørensen's index of similarity between the soil seed bank of exclosure and open area was 0.70 . The similarity of the seed bank between the two land uses is higher than the similarity between the standing vegetation of exclosure and open area. The similarities in species diversity of herbaceous species 
soil seed banks between the enclosed and open area and the high level of similarity index between the standing vegetation in the exclosure and in the open area indicate that the open area, if closed, still has a chance to rehabilitate in the same way as the closed area.

Even though no woody species were found in the exclosures and open area, the possible contribution of the soil seed bank for the process of regeneration shouldn't be ruled out (Kebrom, 2001). The high number of herbaceous and grass species found through sieving and incubation from the seed bank shows its role in providing vegetative protection cover that could help in reducing degradation through erosion. For successful woody vegetation reestablishment, however, the seed and seedling banks may require the supplementary planting of seedlings (Tesfaye and Kebrom, 2000).

\section{Conclusion}

The vegetation in the exclosure has a significantly higher woody vegetation density than the corresponding open area. Exclosures show a positive impact on density but they didn't show a positive impact on diversity. The ground cover is much better in the exclosure than in the open area, thus supporting further regeneration because of better soil conditions and microclimate. The main reason for not finding woody seeds in the soil seed bank both in the exclosure and open area is related to the high level of degradation in the area. Therefore, recruitment from the soil seed bank is doubtful if not impossible. The dominance of the seed bank by herbaceous species indicates that the area is at the early stage of succession.

\section{References}

Alemnew, A. 2001. Diversity and socio-economic importance of woody plants on the peninsula of Zegie, northwestern Ethiopia: implication for their sustainable utilization. Swedish University of Agricultural Sciences. Upsalla, Sweden.

Avena, G. and Ricotta, C. 2000. A parametric index of community evenness. Ecoscience 7: 511515.

Bendz, M. 1986. Hill side closures in Wello. Ethiopian Red Cross society: Mission report. Vaxjo, Sweden.

Bergston, J. 1993. An investigation of soil seed banks in kondoa eroded area, Tanzania. Department of ecological botany. Uppsala University.

BOANARD, 1999. Bureau of agriculture and natural resources of Tigray: Five-year implementation plan. Mekelle, Ethiopia.

Demel, T. 1997. The impact of clearing and conversion of dry afromontane forests into arable land on the composition and density of soil seed banks. Acta Oecologia 18: 555-573.
Demel, T. and Granström, A. 1995. Soil seed banks in dry afromontane forests of Ethiopia. Journal of Vegetation Science 6: 777-786.

Demel, T. 1996. Seed ecology and regeneration in dry Afromontane forests of Ethiopia. Phd Dissertation. Swedish University of Agricultural Sciences, Umea, Sweden.

Demel, T. 1998. Germination of Acacia origena, A. pilispina and Pterolobium stellatum in response to different pre-sowing seed treatment, temperature, and light. Journal of Arid Environments 38: 551-560.

Denslow, J.S 1987. Tropical rain forest gaps and tree species diversity. Annual Review of Ecology and Systematics 18: 431-451.

Feyera, S.1998. Native woody species regeneration under the canopies of tree plantations of Munnesa Shasemene forest project area, southern Oromia, Ethiopia. M. Sc. Thesis. Wendogenet College of Forestry. Report No. 38.

Friss, I.B 1992. Forests and forest trees of northeast tropical Africa: Their natural habitats and distribution patterns in Ethiopia, Djibouti, and Somalia. RBG Kew, London.

Garwood, N.C 1989. Tropical soil seed banks. In: Leck, M.A. Parker, V.T. and Simpson, R.L. (eds.). Ecology of soil seed banks. San Diego.

Getachew, E. 1999. Population structure and regeneration of the main tree species in the acacia woodland in the rift valley of Ethiopia: Assessment of fuel wood resources in acacia woodlands in the rift valley of Ethiopia. Doctoral thesis. Swedish University of Agricultural Sciences, Umea, Sweden.

Granström, A. 1986. Seed banks in forest soils and their role in vegetation succession after disturbance. Phd Dissertation. Swedish University of Agricultural Sciences, Upssala, Sweden.

Hedberg, I. and Edwards, S. 1995. Flora of Ethiopia. Volume II. Addis Ababa and Asmara, Ethiopia. Upssala, Sweden.

Heinz, E. D., Dieter, M. 1972. Aims and methods of vegetation ecology. John Wiley and Sons. London.

Jerry, S. 1992. The role of seed banks in vegetation dynamics and restoration of dry tropical ecosystems. Journal of Vegetation Science 3: 357-360.

Kebrom, T. 2001. Natural regeneration of degraded hill slopes in southern Wello, Ethiopia: a study based on permanent plot. Applied Geography 21: 275-300.

Kebrom, T. and Tesfaye, B. 2000. The role of soil seed banks in the rehabilitation of degraded hill slopes in southern Wello, Ethiopia. Biotropica 32: 23-32. 
Kent, M. and Paddy, C. 1992. Vegetation description and analysis: a practical approach. Belhaven, London.

Krebs, C.J 1999. Ecological methodology. Addison Wesley Longman Inc., England.

Leck, M.A., Parker, V.T. and Simpson, R.L. 1989. Ecology of soil seed banks. Academic press, San Diego.

Lyarru, H.V.M. 1995. Seed bank dynamics of the formerly overgrazed Kondoa Irangi hills, central Tanzania. Stockholm University.

Lyarru, H.V.M. 1996. Characterization of the seed bank on degraded hill slopes in Kondoa Irangi Hills, Tanzania. University of Dar-es-salaam, Tanzania.

Lyarru, H.V.M. and Backeus, I. 1999. Soil seed bank and regeneration potential on eroded hill slopes in the Kondoa Irangi hills, central Tanzania.

Lyarru, H.V.M., Eliapenda, S. and Backeus, I. 2000. Floristic, structural, and seed bank diversity of a dry afromontane forest at Mafai, central Tanzania. Biodiversity and Conservation 9: 241-263.

Magurran, A.E. 1996. Ecological diversity and its measurement. Chapman and Hall. London.

Mcneely, J.A. 1995. Protected areas for the 21 century: working to provide benefits for society. Fao - Unasylva 45: 176.

Medanie, W. 1997. Socio ecological impacts of area closure: a case of Semenawi -bahri and Temtem sites, Eritrea. Agricultural University of Norway.

Mekuria, A., Demel, T. and Olsson, M. 1999. Soil seed flora, germination, and regeneration pattern of woody species in Acacia woodland of the rift valley of Ethiopia. Journal of Arid Environments 43: 411-435.

Mwalayosi, B.B.R. 2000. Vegetation changes following land reclamation in the Kondoa Eroded Area, central Tanzania. African Journal of Ecology 38: 265-268.

NMSA, 2002. National metrological service agency: 2002 monthly rainfall. Addis Ababa, Ethiopia.

Peters, M.C. 1996. The ecology and management of non-timber forest products. World cup technical paper no. 322. Washington D.C.

PieLou, E.C. 1975. Ecological diversity. A Wiley Inter- science publication. London.

Roberts, H.A. 1981. Seed banks in soils. Advances in Applied Biology 6: 1-45.

Shiro, T. 1991. Species turnover and diversity during early stages of vegetation recovery on the volcano Usu, northern Japan. Journal of Vegetation Science 2: 301-306.

Sutherland, W.J. 2000. Ecological Census: A handbook. Cambridge University Press, U.K.

Swamy, P.S. 2000. Plant species diversity and tree population structure of a humid tropical forest in Tamil Nadu, India. Biodiversity and Conservation 9: 1643-1669.
Tadesse, W. 1998. Diversity of woody plants and avifauna in a dry afromontane forest: on the central plateau of Ethiopia. Swedish University of Agricultural Sciences.

Tamirat, B. 1994. Studies on remnant afromontane forests on the central plateau of Shewa, Ethiopia. Upsalla University.

Tefera, M. 2001. The role of area closures in the recovery of woody vegetation in degraded hillsides of Biyo and Tiya, central and northern Ethiopia. Swedish University of Agricultural Sciences.

Tesfaye, T. 1996. Problems and prospects of tree growing by smallholder farmers: A case study in Felege-Hiwot locality, eastern Tigray. Swedish University of Agricultural Sciences. Skinnskatteberg, Sweden.

TFAP, 1996. Tigray forestry action plan. Mekelle, Ethiopia.

Thomson, K. and Grime, J.P. 1979. Seasonal variation in the seed banks of herbaceous species in ten contrasting habitats. Journal of Ecology 67: 893-921.

Verma, Shadangi, R.D.K., Kunhikannanan, C. and Tottery, N.G. 1999. Impact of plantation in degraded land on diversity of ground flora, soil micro flora and fauna and chemical properties of soil. Tropical Ecology 40: 191-197.

Xueying, Z. 1997. Rehabilitation and development of forest on degraded hills of Hong Kong. Forest Ecology and Management 197-201. 